\title{
The Ethics of Genetic Engineering An Islamic Viewpoint
}

DOI: http://dx.doi.org/10.5915/22-3-14246

For a brief buc necessary orientacion. Islam is the last of the three monotheistic Abrahamic religjons following Judaism and Christianity. Islam recognizes and respects both religions. upholds their same moral code. but takes exception to some doctrinal issues that Islam reckons to be innovations in the two religions. Besides the spiritual side, Islam broughi forward the outlines of a comprehensive legal system covering all aspects of human life. The system is flexible enough 10 allow the human mind to legislate for a changing world and varying circumstances. However. this flexibility and ability to legislate is limited within the boundaries of a general frantework. It is this system that is called the "Shari'ah" or Islamic jurisprudence. If we describe the principles of this system, if will perhaps be possible 10 apply them to "genetic engineering", which in spite of an initial brief moratorium, has grown in record time from the domain of laboratory research to that of applied biotechnology. This has far reaching actual and potencial implications.

Let us first consider the attitude of Islam towards science. Not only was there never confrontation between them. but the pursuit of knowledge is a religious duty upon every muslim. man or woman. In Islamic juridical terminology, the equivalent of the 1csm "sciensific rescarch" is called "Ihe revealing of Allah's traditions in His creation", and is part of Man's duty as God's trustee over this planet. Because there is no clergy-institution in Islam, there was no censorship over research. During the era of Islamic civilization, muslim and nonmuslim scientists experienced no impediment to unfolding their [ull potential. This helped Europe out of the dark ages by bridging Europe's gap between the Greek civilization, and the renaissance. Islam has never put an obstacle to scientific research, including that pertaining 10 generic engineering.

When it comes 10 application, however, five Islamic governing rules roust be reviewed.

The first comprises the five goals of Jurisprudence,

Presented 10 Conference on Eshics of Genelic EnginceringGeorge Washington University and Costello Instilute, Ocruber 1989. specified as the preservation and protection of self (i.e., life), mind, faith, ownership and procreation.

The second is Alläls's gift to humanity expressed in the Qur'ān. Allăh says:

"And $\mathrm{He}$ has made subservient 10 you, as from Himself, all that is in the heavens. and on earth ..."

This verse is incerpreted by exegists as endowing Man with the creative mind and giving him the mandate to make conscious use of nature and all the creatures. It seems that these two rules ingether give the human race a free hand to harness and manipulate nature in any way that ensures the fulfillment of the five specified goals of Jurisprudence.

This, however, does nol mean that the road has been opened to be trodden without safeguards or warning signals and here comes our third rule, in the form of a Qur'änic verse which stands out and catches attention when one ponders on the subject of genetic enginecring. This verse sefers to "changing Alläh 's creation" and there is a story behind it. The Qur'änic version of the story of Adam and Eve reports that Satan tempted both to eat from the forbidden tree, they both sinned by disobeying Alläh. they both repented, and were both forgiven. After that they were entrusted with the noble mission of popularing planer earth, and the human race 10 act as Aläh's vicegerent therein. This version is a departure from that which charges Eve of being the prime culprit and the human race to have been sent to earth in punishment, and that every human being therefore is born in sin. When Satan saw the curve of events in favor of man whom he had planned to misguide and that man was eventually forgiven and honored by Allah and chosen for vicegerency on earth, Satan did not despair and asked Alläh for a second chance to chase Adam and his progency on earth and put them to the test again. Allah grauted the request, but said $\mathrm{He}$ would provide them with such guidance that would immunize them against Satan's temptations, except for those who willfully reject Allāh's guidance in favor of Saran's temptations. In an expression of this plan to lead mankind astray, the Qur'an quotes the rebellions Satan addressing Allah about the humar race. 
"... Verily of thy servants I shall mose certainly take my due share. I shall lead them astray and fill them with vain desires. And I shall command them so that they cut off the ears oi cattc (in idolatrous sacrifice) and I shall command them and they will change Altah's creation. But all who take Satar rather than Alläh for their master do incleed most clearly lose all. He (Satan) holds out promises 10 thern and fills them with vain desires, yet whatever Satan promises them is but meant to delude the mind."

The expression of "changing Allāh's creation" in answer to Satan's tempcation has commanded attention and generated debate over the cencuries. In vogue nowadays is its application on surgical sexual conversion of men inlo wornen and vice versa unless it is corrective surgery to restore the real sex. Genetic engineenring is certainly a very inviting field to consider the invocation of this verse. After all, has not gencric engineering gone furcher than the mere changing to the capability of producing new creatures hitherto unknown in the natural order of creation? Fortunately, however, it is the consensus that this verse irom the Qur'an can not be taken as a ban on genetic engineering or elisc, if carried too har. it might be made to conflict with many forms of therapeutic surgery including appendeclomy, tonsilleciomy, cholecystectomy and oihers that may be life saving and life promoting although they entail a change in Allāh's creation.

The sources of legislation in Islam are the Qur'ann (Allah's word), the teachings of prophet Mubammad called "Tradition" or "Sunnah" and for issues not spelled out in the Qur'ān and Sunnah legislation is to be based on legitimate reasoning, i.e., "Yjtihād" and analogy, i.e., "Qiyãs". Since neither the Qur'ān nor Sunnah made mention of genetic engineering, the ruling is based on legitimate reasoning, i.e., reasoning which does not conflict witly the spirit of Islam or the given goals of the Jurisprudence, i.e., preservation of life, mind, faith, ownership, and procreasion. A juridical rule is in operation for such situations not specified in Qur'ān or Sunnah and this is our fourth guiding rule, the text of which is "Whorever the welfare exists, there stands the stature of Alläh." The feasible conclusion therefore is that there are no restrictions on genetic engineering research, but that the entry of the fruiss of that research into the realm of widespread applied biotechnology should be allowed, one by one, only through the filter of juridical sanction ensuring its compliance with the benefit to humanity, the heeding of the fifth rule, which is the juridical diclum that reads: "Harm and harming are not of Islam". Applications leading to enhancement of human life, health, and welfare are not only permissible but are an act of charity that is commendable and rewardable by Allāh. Dangerous applícations, expressed by early concerns in the seventies about the military exploitation of biotechrology in biological warfare are obviously objectionable. So are exotic applications, or doing things only and solely because they can be done, or 10 assuage curiosity or to interfere with the integrity of the human personality, and its eligibility for personal accountability or to promole desires and inclinations that are prohibited by Islam. In all cases, rigorous precautions should be made 10 guard against unforeseen untoward complications that in this particular fieid might prove disastrous, even at the cost of resisting the burning desires to be the forerunner or the first on the market. Some genie might be unleashed out of its bortle one day and wreak devastation beyond control, either direclly or by a chain reacion it sets off.

It is not possible to recount the applications of genetic engineering one by one, nor is it possible to look into the future for the hitherto unforescen applications of this very fertile technology, but a few examples and projections are nol oul of place. Ncw bacteria have been crealed 10 serve the pharmaceutical, nutritional, industrial and other needs of Man, but the fear that some lethal new forms of organisms might inadvertently escape out of the laboratories and cause devastating epidemics still looms. The possibility of misplaced genes eventually finding their way into the cells of human beings and producing cancer has been voiced. Not only are new plant forms are bcing created, but the whole concept of agriculture as a human need might wcll be revolulionized beyond recognition with far reaching implications upon labor and upon the environnent.

Ал easy applicacion to commend is gelle therapy to corred genetic errors. It is the equivalent of organ Iransplantation at the molecular level, although its application at the germ line level will certainly be an innovation when its time comes. But what about the application of similar eugenic technigues when behavioral and personality genes become idenifiable and amenable to transfer? Shall the ridding of Man of disease slide into the genetic betterment of human stock? And who should decide what betterment means? And from whose poinl of view? Shall Man be made to order according to a predesigned blue print? Or would this upset the human order in its totality based on variety and variability of physical, mental and spiritual atributes?

Another window of possibilities has recently becn opened with the relatively easy introduction of sizeable cuts of human DNA into rat germ cells. There seems to be no doubt that furcher manipula. tion of these techniques, fueled by the scientinic nare to pursue the unknown, will result - amongs onker things - in the blurring of genetic identify of species and the compromising of interspecies barriers. Should one be scientifically curious about the extent 
to which animals can be humanized and the extent to which Man can be animalized? And who is to set the rules of this game and acquire the mastery over its tremendous power? Is it science and the scientists? But does not science admit its incompleteness as it gropes for more knowledge by research inio the vast expanse of our ignorance? W'hen the first alomic bomb was dropped over Hiroshima, Oppenheimer said: "Today physicists have known sin". Will the day come when biotechnologists inadvertently fall in10 sin, albeil with much more at stake?

But the ethics of genetic enginecring go beyond concepts and technjcalities. Biotechnology has launched a revolution wider than the prefix "bio" implics. Life forms have been potented and the voracious appetite of industrial capical has been aroused. Scientists' past contenement with their ivory lowers has eroded now that golden lowers compele. Capilal is interested in profil rather than philanthropy and this will innuence borh science and scien. lists. Competition evokes secrecy and the market direcis research. The issues of accessibility and equity. especially in matters of life and health and especially for the poor and underprivileged, should be a concern.

When the question of scientific control was raised in the early seventies and whether it was to be entrusted 10 the politicians or the scientists, it was my prayer that neither the politicians nor the military would grab it. With the contemporary marriage between scientists and industry. one can see the blessings, but also the reservalions. Cenius has a right to be amply rewarded bur also a duly to be graciously discharged. A balance should be maintained. This "balance" is described several times in the Qur' ān. Allàh says:

"ll is Alls̄h who has sent down the book Qur'ān in truth, and the balance (by which 10 judge right and wrong)".

"And the firmament has $\mathrm{He}$ rajsed high and $\mathrm{He}$ has set up the balance of Justice in order that you may not transgress this balance."

As scientisis decipher the creation they should be mindful of the Creator, for as the Qur'ăn says:

"... Amongst Mis worshippcrs, the learned heed
him most..."

In view of all this perhaps it is time for an Ethical Code of Genetic Engineering to be written, before we are overtaken by its rapid pace and before shoricornings are rooted beyond reversal. All concerned should give their input towards that code, which even if not legally binding should be morally guiding. In this respect, 1 am confident that the vast area of commonalities will provide for the formulation of a Judeo-Christian-Islamic elhic for generic engineering.

Hassan Hathoul, M.D., Ph.D.

Las Angeles, CA

From the Islamic Center of Sourhern California Los Angeles, $C A$

Reprin Requeses: H. Hathout, M.D. Islumic Center of Sourhern Californio 434 South Vermont. Los Angeles, CA 90023

\section{References}

1. Glorious Qur'ān, Chapler 45, Verse 13.

2. Cilorious Qur'ān, Chapter 4, Verse 118-320.

3. Glorious Qur'ān, Chapier 42, Verse 17.

4. Glorious Qur'än, Chapeer 55, Verse 7-8.

5. Glorious Qur'ān, Chapter 35, Verse 28. 